\title{
IDENTIFIKASI KESALAHAN SISWA SMA DALAM MEMBUAT PEMODELAN MATEMATIKA DAN PENYEBABNYA
}

\author{
Rosdati Amira Bahir ${ }^{1}$, Helti Lygia Mampouw ${ }^{2}$ \\ 1,2 Universitas Kristen Satya Wacana, Jl. Diponegoro 52-60 Salatiga \\ 202016024@student.uksw.edu, helti.mampouw@uksw.edu
}

\begin{abstract}
This research aims to describe senior high school students' error in creating mathematical modeling and the factors which cause to. The subjects consisted of 9 students from SMA Negeri 1 Tuntang who were obtained by snowball technique. The data obtained from the results of observations and in-depth interviews with the subjects. The results showed that students ' error in creating mathematical modeling are students cannot identify the variables on the problem, so they didn't have the variables to be mathematical model, students didn't make assumptions about the models that will be formulated into equations, and also the students had an error in formulating and resolving equations. The error is caused by internal and external factors. The internal factors are lack of practice in doing an exercise about the story questions, not knowing about mathematical modeling and the importance of mathematical modeling to solve the story question, using reasoning or their own instincts to solve word problems; and external factors namely the level of difficulty of the given questions and the lack of learning infrastructure such as sourcebooks or other sources.
\end{abstract}

Keyword: Errors, Causes, Mathematical Modeling

\begin{abstract}
Abstrak
Penelitian deskriptif kualitatif ini bertujuan untuk mendeskripsikan kesalahan siswa SMA dalam membuat pemodelan matematika dan faktor-faktor yang menyebabkan terjadinya kesalahan tersebut. Subjek terdiri 9 siswa SMA Negeri 1 Tuntang yang diperoleh dengan teknik snowball. Data diperoleh dari hasil observasi dan wawancara terhadap subjek penelitian. Hasil penelitian menunjukkan bahwa kesalahan siswa dalam membuat pemodelan matematika yaitu siswa tidak mengidentifikasi variabel-variabel pada soal sehingga tidak memeiliki jabaran variabel untuk menjadi model matematika, siswa tidak membuat asumsi tentang model matematika yang akan dibentuk menjadi persamaan matematika, serta siswa salah dalam membentuk dan menyelesaikan persamaan matematika. Kesalahan tersebut disebabkan oleh faktor internal yakni siswa tidak mengetahui tentang pemodelan matematika dan pentingnya pemodelan matematika untuk menyelesaikan soal cerita, kurang latihan mengerjakan soal-soal cerita, menggunakan cara nalar atau insting sendiri dalam menyelesaikan soal cerita dan faktor eksternal yakni tingkat kesulitan soal yang diberikan dan kurangnya sarana prasarana seperti buku sumber ataupun sumber lainnya.
\end{abstract}

Kata Kunci: Kesalahan, Penyebab, Pemodelan Matematika.

Pemodelan merupakan aspek penting yang merepresentasikan masalah secara terstruktur, baik simbolik maupun verbal. Pemodelan matematika adalah suatu deskripsi dari beberapa masalah dunia nyata ke dalam matematika yang disebut dunia matematika (Dym \& Ivey, 2004). Pemodelan matematika merupakan salah satu cara untuk merepresentasikan persoalan kompleks ke dalam bentuk matematika (Ndii, 2018). Pemodelan matematika adalah bentuk simbolik dari masalah yang biasanya berbentuk soal cerita (Widowati \& Sutimin, 2007). Berbagai bentuk simbolik digunakan manusia pada kehidupan sehari-hari (Andriani, 2019) . Pada pembelajaran matematika, pemodelan matematika membantu siswa berpikir logis salah satunya dengan diberikan soal matematika yang bersifat pemecahan masalah nyata dalam bentuk soal cerita.

Kesalahan siswa dalam menyelesaikan soal cerita umumnya disebabkan oleh kesalahan dalam memodelkan matematika. Kesalahan tersebut beragam bentuknya karena setiap siswa memiliki 
Identifikasi Kesalahan Siswa SMA dalam Membuat Pemodelan Matematika dan Penyebabnya, Rosdati Amira Bahir, Helti Lygia Mampouw

karakteristik yang berbeda-beda (Zulfah, Astuti, Insani, Zulhendri, \& Akbar, 2019). Kesalahan siswa menunjukkan keterbatasan sehingga keterbatasan siswa dapat dilihat dari adanya kesalahan dalam menyelesaikan masalah matematika. Kesalahan yang timbul dalam penyelesaian soal matematika didefinisikan sebagai penyimpangan atau kekeliruan jawaban tertulis siswa (Sari, 2018). Kesalahan siswa dalam menyelesaikan soal cerita matematika merupakan suatu masalah yang harus diidentifikasi setiap tahapan penyelesaian (Zulyanty, 2019). Soal cerita menjadi hal yang sulit diselesaikan sebagian siswa karena memerlukan pemahaman dan pemikiran logis (Budiyono, 2008).

Beberapa hasil penelitian topik serupa telah ditemukan oleh peneliti lain yang melihat kesalahan pemodelan matematika dari sisi siswa. Pada penyelesaian soal cerita, siswa tidak memahami arti atau maksud kalimat dalam soal, tidak dapat membuat pemodelan matematika yang benar dan kurang teliti dalam menentukan informasi mengenai apa yang diketahui (Rindyana \& Chandra, 2013). Selain itu, siswa melakukan kesalahan dalam memahami konsep, kesalahan dalam menerjemahkan soal ke dalam model matematika, kesalahan dalam menggunakan aturan-aturan atau rumus-rumus matematika, dan kesalahan operasi (Rahmania \& Rahmawati, 2013). Di sisi lain, kesalahan-kesalahan yang dilakukan siswa dalam menyelesaikan soal cerita matematika, diantaranya kesalahan memahami soal, kesalahan membuat pemodelan matematika, melakukan perhitungan, dan penulisan kesimpulan (Gunawan, 2016). Kesalahan yang dilakukan siswa tersebut dapat berimbas pada keterampilan siswa menghadapi persoalan nyata di dalam kehidupan sehari-hari. Oleh sebab itu, perlu ada antisipasi atas kesalahan yang dilakukan siswa dengan cara mengidentifikasi kesalahankesalahan dan menemukan penyebab terjadinya kesalahan tersebut.

Pemodelan matematika merupakan langkah penting di dalam menyelesaikan soal cerita matematika. Kendala dalam pemodelan matematika menjadi representasi ketidakpahaman atas masalah pada soal cerita. Tujuan penelitian ini adalah mengidentifkasi kesalahan siswa dalam membuat pemodelan matematika dan faktor yang menyebabkan terjadinya kesalahan-kesalahan tersebut.

\section{METODE}

Penelitian ini merupakan penelitian deskriptif kualitatif, karena bermaksud untuk memahami fonomena tentang apa yang dialami oleh subjek penelitian misalnya perilaku, persepsi, motivasi, tindakan, dan lainnya, secara holistik, dan dengan cara deskripsi dalam bentuk kata-kata atau bahasa, pada suatu konteks khusus yang alamiah dengan memanfaatkan berbagai metode alamiah (Moleong, 2017: 6). Penelitian deskriptif adalah penelitian untuk menyajikan gambaran tentang sesuatu dengan menggunakan kata-kata (Zulfah, 2017). Penelitian deskriptif kualitatif ini bertujuan untuk mendeskripsikan kesalahan siswa dalam membuat pemodelan matematika dalam menyelesaikan soal cerita serta hal-hal yang menyebabkan kesalahan tersebut, di dalamnya terdapat upaya mendeskripsikan, menganalisis dan menginterpretasikan kondisi yang terjadi. 
Subjek dalam penelitian ini terdiri dari 9 siswa kelas X di SMA Negeri 1 Tuntang. Subjek diambil dengan teknik snowball. Teknik snowball adalah teknik penentuan sampel yang mula-mula jumlahnya kecil, kemudian membesar karena kebutuhan penelitian (Sugiyono, 2014). Subjek penelitian ini mula-mula terdiri dari 3 orang, yang berangsur bertambah menjadi 9 siswa pada saat data telah jenuh. Data yang terkumpul adalah kesalahan-kesalahan siswa dalam membuat pemodelan dan faktor yang menyebabkan kesalahan tersebut. 9 subjek tersebut yaitu TB, DR, MR, SN, LM, VK, $\mathrm{AL}, \mathrm{BC}$, dan DT.

Instrumen utama adalah peneliti sendiri. Selain instrumen utama terdapat instrumen pendukung yakni catatan lapangan berupa catatan saat pengamatan langsung terhadap pembelajaran di kelas, pedoman wawancara dalam upaya menggali hal-hal yang ingin diketahui dari subjek, dan dokumentasi berupa rekaman serta dokumen jawaban tertulis siswa dalam menyelesaikan suatu soal cerita guna mengetahui kesalahan yang dilakukan siswa. Soal cerita yang beserta kunci jawaban soal tersebut adalah sebagai berikut.

\footnotetext{
1. Seorang pedagang memiliki kapal barang bernama NewWave. Namun, karena biaya bahan bakar tinggi yaitu sebesar 0,42 dolar/liter, pemilik kapal sedang berpikir untuk melengkapi kapal dengan parasut. Penggunaan solar setiap tahun tanpa parasut adalah 3.500 .000 liter. Sedangkan parasut berpotensi mengurangi konsumsi solar sekitar $20 \%$. Untuk biaya melengkapi kapal dengan parasut sebesar 2.500 .000 dolar. Setelah berapa tahun penghematan bahan bakar solar akan menutupi biaya parasut?
}

\section{Gambar 1. Soal Cerita}

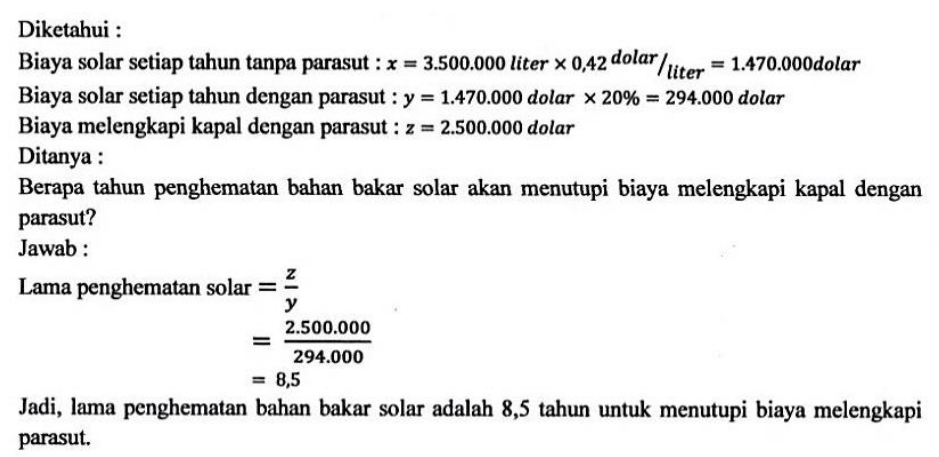

Gambar 2. Kunci Jawaban dari Soal Cerita

Analisis data dilakukan dengan mereduksi data, menyajikan data, dan verifikasi data. Langkah yang ditempuh adalah mereduksi data yang telah didapatkan untuk dipilah atau dikategorisasikan ke dalam bagian-bagian yang memiliki kesamaan. Setelah data di reduksi, selanjutnya menyajikan data dengan uraian teks atau deskripsi teks. Kemudian, langkah terakhir dalam analisis data adalah mengemukakan kesimpulan dari hasil observasi maupun wawancara yang telah didukung dengan bukti-bukti valid.

\section{HASIL DAN PEMBAHASAN}

Hasil penelitian tentang cara siswa menyelesaikan soal cerita menunjukkan bahwa ada beberapa kesalahan yang masih dilakukan siswa dalam membuat pemodelan matematika. Kesalahan-kesalahan 
Identifikasi Kesalahan Siswa SMA dalam Membuat Pemodelan Matematika dan Penyebabnya, Rosdati Amira Bahir, Helti Lygia Mampouw

tersebut disebabkan oleh beberapa faktor. Kesalahan-kesalahan serta faktor penyebabnya dituliskan dalam tabel berikut.

Tabel 1.

Tipe Kesalahan dan Penyebabnya

\begin{tabular}{|c|c|c|}
\hline No & Tipe Kesalahan & Penyebab \\
\hline 1 & $\begin{array}{l}\text { Tidak mengidentifikasi variabel- } \\
\text { variabel pada soal sehingga tidak } \\
\text { membuat jabaran variabel untuk } \\
\text { menjadi model matematika }\end{array}$ & $\begin{array}{l}\text { a. Kesulitan memahami soal } \\
\text { b. Tidak mengetahui cara pemodelan } \\
\text { matematika } \\
\text { c. Keterbatasan informasi mengenai sumber } \\
\text { belajar terkait pemodelan matematika untuk } \\
\text { penyelesaian soal cerita } \\
\text { d. Kurangnya latihan soal cerita }\end{array}$ \\
\hline 2 & $\begin{array}{l}\text { Tidak membuat asumsi tentang model } \\
\text { yang akan di formulasikan ke dalam } \\
\text { persamaan }\end{array}$ & $\begin{array}{l}\text { a. Soal yang rumit } \\
\text { b. Kurang latihan soal cerita } \\
\text { c. Tidak menggunakan pemodelan matematika } \\
\text { melainkan menggunakan cara pemahaman } \\
\text { sendiri }\end{array}$ \\
\hline 3 & $\begin{array}{l}\text { Kurang tepat dalam memformulasikan } \\
\text { dan menyelesaikan persamaan }\end{array}$ & $\begin{array}{l}\text { a. Soal yang diberikan sulit dipahami } \\
\text { b. Jarang mengerjakan latihan soal cerita } \\
\text { c. Kurangnya sumber belajar terkait cara } \\
\text { penyelesaian soal cerita dengan pemodelan } \\
\text { matematika }\end{array}$ \\
\hline
\end{tabular}

Kesalahan tipe 1: Tidak mengidentifikasi variabel-variabel pada masalah sehingga tidak memiliki jabaran variabel untuk menjadi model

Kesalahan pada tipe 1 merupakan kesalahan karena subjek tidak menyelesaikan soal dengan mengidentifikasi variabel-variabel yang terdapat pada soal cerita sehingga tidak ada jabaran mengenai variabel untuk menjadi model. Pada kesalahan ini terjadi pada 3 subjek yaitu TB, DR, dan MR. Kesalahan terjadi karena subjek hanya menulis kembali soal yang diberikan. Selain itu, ada variabel yang tidak ia identifikasi melainkan hanya menulis kembali angka-angka yang diketahui pada soal. Berikut adalah contoh jawaban subjek yang termasuk dalam kesalahan tipe 1.

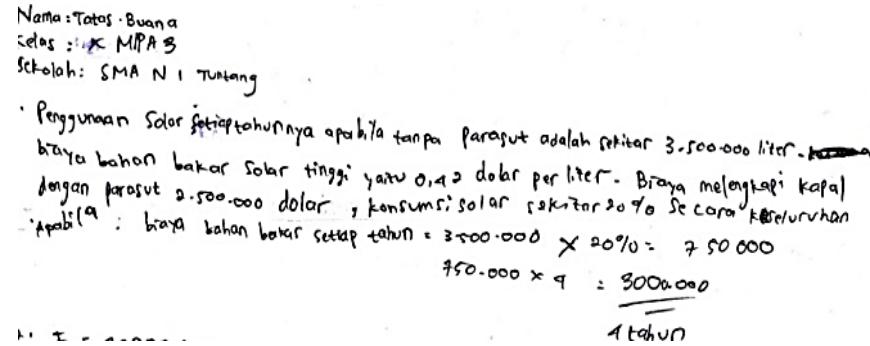

Gambar 3.a. Hasil Jawaban Subjek

Kesalahan Tipe 1. Tidak Mengidentifikasi VariabelVariabel yang Terdapat pada Soal

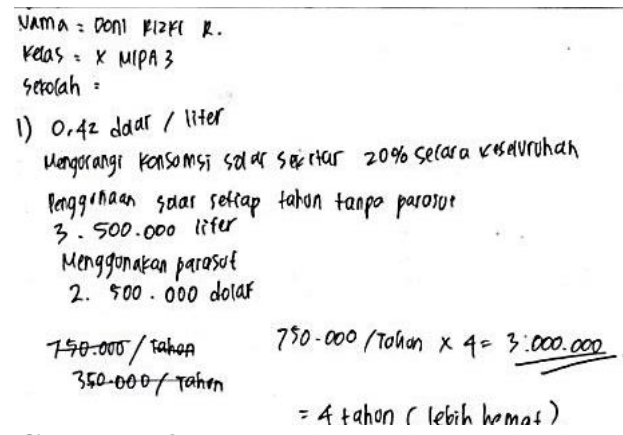

Gambar 3.b. Hasil Jawaban Subjek

Kesalahan Tipe 1. Tidak Mengidentifikasi Variabel-Variabel yang Terdapat pada Soal 
Observasi dilakukan untuk menggali informasi kesalahan yang terjadi dalam penyelesaian soal, kemudian wawancara untuk mengetahui penyebab terjadinya kesalahan tersebut. Didapatkan hasil bahwa kesalahan terjadi disebabkan karena soal yang diberikan rumit. Selain itu, subjek menggunakan cara nalar atau cara sendiri karena tidak mengetahui cara dengan pemodelan matematika. Hal tersebut dikarenakan keterbatasan informasi mengenai sumber belajar terkait pemodelan matematika untuk penyelesaian soal cerita. Kurangnya latihan soal juga menyebabkan siswa tidak terampil dalam menyelesaikan soal. Hal tersebut dapat dilihat dari hasil wawancara dengan subjek sebagai berikut.

P : Tapi kamu selalu menyelesaikan dengan cara tersebut atau tidak?

TB : Tergantung sih mba, kadang pakai cara kadang mengarang saja.

P : Kesulitan apa yang kamu alami saat menyelesaikan soal?

TB : Masih bingung memahami nya, soal nya susah-susah gampang, harus memahami betul.

Wawancara di atas adalah wawancara terhadap subjek TB, dari hasil wawancara ia mengatakan memang jarang latihan soal dan saat menyelesaikan soal menggunakan cara sendiri atau mengarang karena susah memahami soal yang diberikan.

DR : Ya soalnya emang susah.

$\mathrm{P}$

Selain itu guru menginformasikan menggunakan sumber buku atau sumber lain terkait cara penyelesaiannya?

DR : Tidak, jarang.

Cuplikan wawancara terhadap subjek DR di atas menunjukkan bahwa subjek masih bingung dengan soal. Selain itu subjek mengatakan bahwa guru juga tidak memberikan informasi mengenai sumbersumber yang dapat digunakan terkait soal cerita matematika.

P : Jadi, kamu menyelesaikan soalnya tuh gimana?

MR : Ya, kadang pakai nalar saja.

P : $\quad$ Kesulitan yang kamu temui tuh apa?

MR : Yang diketahui di soal itu membingungkan.

Wawancara dengan subjek MR tersebut mendapatkan jawaban bahwa ia memang tidak mengetahui tentang pentingnya pemodelan matematika, lebih sering menggunakan cara nalar, dan jarang latihan soal cerita. Selain itu, ia merasa bingung dengan soal yang diberikan. Ia juga mengatakan tidak ada sumber informasi mengenai cara pemodelan matematika dalam menyelesaikan soal cerita.

\section{Kesalahan tipe 2: Tidak membuat asumsi tentang model yang akan di formulasikan ke dalam persamaan}

Kesalahan tipe 2 adalah kesalahan dimana subjek tidak membuat asumsi mengenai model yang akan dibentuk ke dalam persamaan. Pada tipe kesalahan 2 ini terjadi pada 7 subjek yaitu TB, DR, MR, SN, LM, VK, dan AL. Subjek TB, DR, dan MR melakukan kesalahan pada tipe kesalahan 2 ini karena memang melakukan tipe kesalahan 1 karena tidak menjabarkan variabel untuk menjadi 
model, sehingga tidak ada model yang diasumsikan. Pada subjek lain, kesalahan terjadi karena menyelesaikan soal dengan langsung mengoperasikan variabel yang dituliskannya tanpa membuat asumsi mengenai model terlebih dahulu. Berikut adalah contoh jawaban subjek yang termasuk dalam kesalahan tipe 2 .

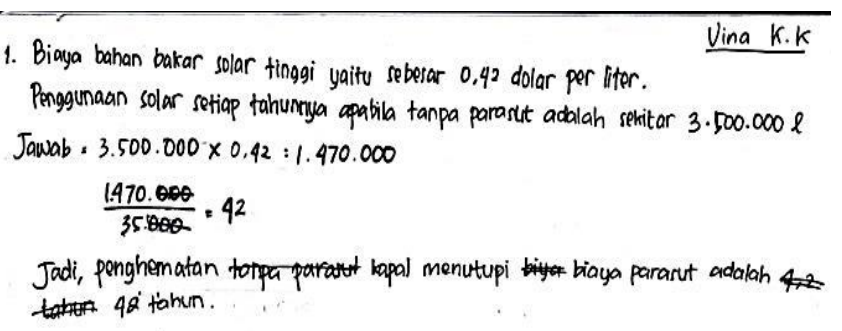

Gambar 4.a. Hasil Jawaban Subjek

Kesalahan Tipe 2. Tidak Membuat Asumsi Kesalahan Tipe 2. Tidak Membuat Asumsi Mengenai Model yang akan Dibentuk ke dalam Mengenai Model yang akan Dibentuk ke Persamaan Matematika

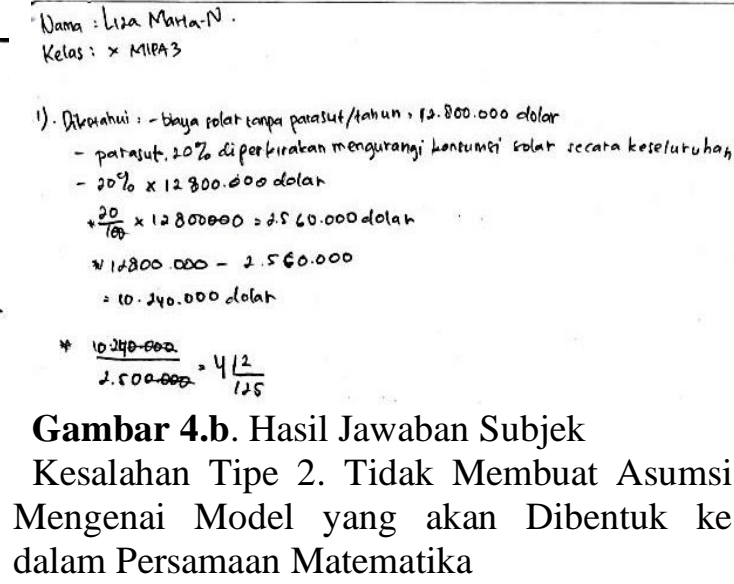

Gambar 4.b. Hasil Jawaban Subjek dalam Persamaan Matematika

Hasil observasi dan wawancara mendapatkan hasil bahwa ada beberapa faktor yang menyebabkan terjadinya kesalahan dalam membuat pemodelan matematika ini, diantaranya yaitu karena soal yang rumit, jarang latihan soal cerita, dan menggunakan cara sendiri. Berikut hasil wawancara dengan subjek.

P : $\quad$ Dari jawaban kamu kan kamu tidak menggunakan pemisalan model tuh?

SN : Nah, iya.

P : $\quad$ Itu kenapa?

SN: $\quad$ Sulit banget soalnya, kalimat nya itu susah dipahami.

Terlihat pada wawancara dengan subjek SN di atas, saat ditanya mengapa ia tidak membuat asumsi mengenai model matematika, ia mengatakan bahwa ia tidak melakukan hal tersebut karena soal yang diberikan terlalu sulit untuk dipahami dan ia jarang mengerjakan latihan soal cerita.

P : $\quad$ Tapi saat kamu menyelesaikan soal itu, apa yang kamu lakukan?

LM : Pertama tuh pakai feeling, trus di coba-coba udah gitu aja.

P : $\quad$ Menurut kamu itu sulit atau tidak?

$\mathrm{LM}$ :

Sulit, memisalkannya itu sulit karena memahami soal nya tuh terlalu sulit.

Cuplikan wawancara dengan subjek LM di atas terlihat bahwa subjek mengatakan bahwa lebih banyak menggunakan insting dan melakukan coba-coba. Ia merasa sulit dalam memisalkan variabel yang diketahui karena susah memahami soal dan terdapat angka-angka yang mengecoh di dalam soal. Selain itu ia mengaku belum mengetahui tentang pemodelan matematika.

P : $\quad$ Berarti kalau tidak menggunakan itu karena apa?

VK : Soalnya susah jadinya kurang paham. 
Saat wawancara subjek VK tersebut, subjek mengaku bahwa dalam menyelesaikan soal cerita, ia jarang menggunakan pemodelan matematika dan hanya terkadang saja menggunakannya. Ia kesulitan menggunakan pemodelan matematika karena soal yang diberikan terlalu rumit sehingga membuat ia menggunakan cara sendiri untuk menyelesaikannya.

P : $\quad$ Tapi kenapa saat menyelesaikan soal tidak menggunakannya?

AL : Kalau saya itu sepaham saya bisanya gimana, tapi kadang ya pakai pemisalan.

Cuplikan wawancara di atas merupakan wawancara dengan subjek AL. Terlihat bahwa subjek mengatakan menyelesaikan soal dengan pemahaman ia sendiri karena kesulitan dalam memahami soal.

\section{Kesaahan tipe 3: Kurang tepat dalam memformulasikan dan menyelesaikan persamaan}

Kesalahan tipe 3 adalah kesalahan dalam memformulasikan dan menyelesaikan persamaan matematika. Kesalahan terjadi pada 9 subjek yang terdapat pada penelitian ini. Pada subjek TB, DR, MR, SN, LM, VK, dan AL melakukan kesalahan ini karena tidak membuat asumsi tentang model yang diketahui pada soal sehingga tidak ada yang diformulasikan ke dalam persamaan. Pada subjek BC dan DT, kesalahan terjadi karena tidak tepat dalam penulisan persamaan yang telah diformulasikan. Berikut adalah contoh penyelesaian subjek dengan tipe kesalahan 3.

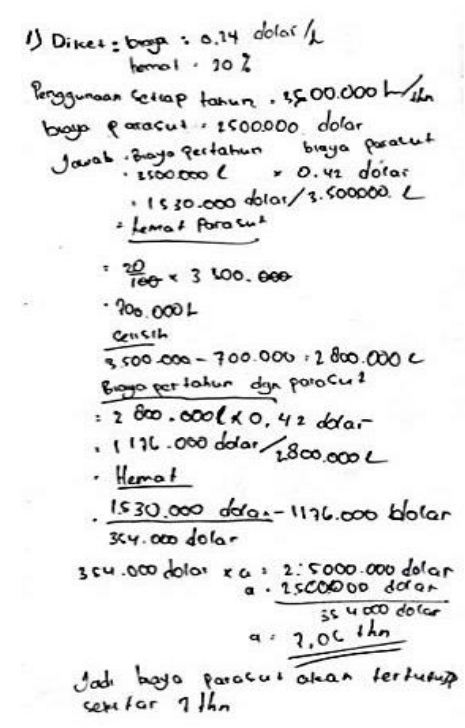

Gambar 5.a. Hasil Jawaban Subjek Kesalahn Tipe 3. Kesalahan dalam Membuat Persamaan Matematika.

Wawancara terhadap subjek menunjukkan faktor yang mempengaruhi terjadinya kesalahan tersebut karena soal yang diberikan sulit, jarang mengerjakan latihan soal dan kurangnya sumber belajar terkait cara penyelesaian soal cerita dengan pemodelan matematika. Hal tersebut dapat dilihat pada hasil wawancara dengan subjek sebagai berikut.

P : $\quad$ Kesulitan apa yang kamu temui saat menyelesaikan soal cerita itu?

BC : Soalnya sulit mba, membuat bingung.

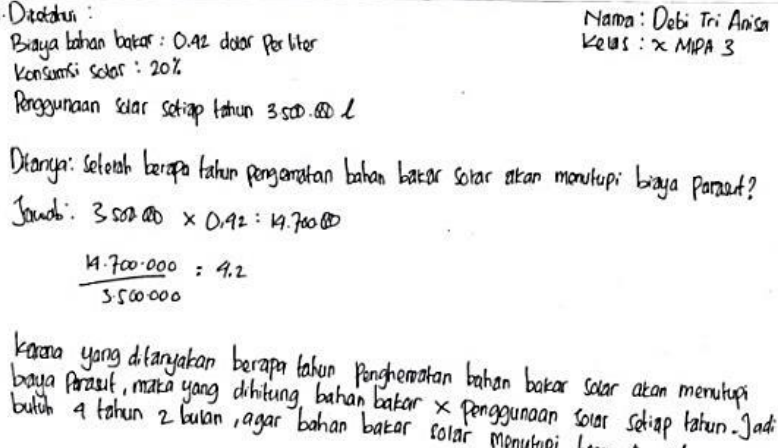

Gambar 5.b. Hasil Jawaban Subjek

Kesalahn Tipe 3. Kesalahan dalam Membuat Persamaan Matematika. 
Identifikasi Kesalahan Siswa SMA dalam Membuat Pemodelan Matematika dan Penyebabnya, Rosdati Amira Bahir,

Wawancara dengan subjek BC di atas dapat dilihat bahwa subjek mengaku jarang mengerjakan latihan-latihan soal cerita. Selain itu, ia mengatakan soal yang diberikan sulit dan membuat bingung.

P : Kesulitan lain saat menyelesaikannya?

DT : Soalnya emang susah di pahami dan jarang latihan soal.

P : Apakah kamu menggunakan buku atau sumber lain?

DT : Paling dari catatan-catatan aja sih mba. Catatan dari gurunya.

Cuplikan wawancara dengan subjek DT terlihat bahwa subjek memang merasa kesulitan menyelesaikan soal cerita terutama dalam membentuk ke dalam bentuk persamaan matematika karena soal yang diberikan sulit dipahami dan membingungkan. Selain itu, ia juga mengaku hal tersebut karena jarang latihan soal. Subjek mengatakan bahwa tidak ada informasi mengenai buku atau sumber-sumber yang dapat digunakan melainkan hanya catatan catatan saja.

Berdasarkan data analisis hasil observasi dan wawancara ke-9 subjek, terdapat beberapa kesalahan siswa dalam membuat pemodelan matematika diantaranya yaitu 3 dari 9 subjek tidak mengidentifikasi variabel-variabel pada masalah sehingga tidak memiliki jabaran variabel untuk menjadi model, 7 dari 9 subjek tidak membuat asumsi tentang model yang akan di formulasikan ke dalam persamaan serta semua subjek melakukan kesalahan dalam memformulasikan dan menyelesaikan persamaan. Kesalahan-kesalahan tersebut disebabkan oleh beberapa faktor, salah satu faktor tersebut adalah faktor yang timbul dari dalam diri sendiri yaitu kurangnya latihan-latihan soal cerita, tidak mengetahui tentang pemodelan matematika dan pentingnya pemodelan matematika untuk menyelesaikan soal cerita serta sering menggunakan cara nalar sendiri atau mencoba-coba. Selain itu faktor dari luar diri siswa juga mempengaruhi siswa melakukan kesalahan dalam membuat pemodelan matematika yaitu didapatkan bahwa soal yang diberikan terlalu rumit sehingga sulit untuk dipahami, tidak mendapat buku atau informasi mengenai sumber-sumber terkait cara menyelesaikan soal cerita maupun tentang pemodelan matematika.

Penelitian yang dilakukan oleh Nugroho didapatkan bahwa salah satu faktor yang mempengaruhi kesalahan siswa dalam menyelesaikan soal cerita adalah siswa belum mampu menerjemahkan soal ke dalam model matematika (Nugroho, 2017). Selain itu, penelitian yang dilakukan Rindyana dan Chandra mengatakan bahwa kesalahan yang berasal dari siswa disebabkan karena siswa tidak memahami arti atau maksud kalimat dalam soal, tidak dapat mentranformasi apa yang mereka ketahui ke dalam kalimat matematika yang benar dan kurang teliti dalam menentukan informasi mengenai apa yang diketahui (Rindyana \& Chandra, 2013). Dalam penelitian ini ditemukan bahwa siswa belum mampu menerjemahkan soal ke dalam model matematika karena tidak mengetahui tentang pemodelan matematika, jarang mengerjakan latihan soal cerita, sering menggunakan cara nalar sendiri atau coba-coba, soal yang diberikan terlalu rumit, serta kurangnya sumber penunjang belajar siswa terlebih tentang pemodelan matematika untuk menyelesaikan soal cerita. 


\section{KESIMPULAN}

Kesalahan siswa dalam membuat pemodelan matematika adalah siswa tidak mengidentifikasi variabel-variabel pada masalah sehingga tidak memiliki jabaran variabel untuk menjadi model, tidak membuat asumsi tentang model yang akan di formulasikan ke dalam persamaan, serta salah dalam memformulasikan dan menyelesaikan persamaan. Kesalahan yang berasal dari faktor internal diantaranya siswa kurang latihan mengerjakan soal-soal cerita, tidak mengetahui tentang pemodelan matematika dan pentingnya pemodelan matematika untuk menyelesaikan soal cerita, serta menggunakan cara nalar atau insting sendiri dalam menyelesaikan soal cerita. Kesalahan yang berasal dari faktor eksternal diantaranya soal cerita yang diberikan sulit dan kurangnya sarana prasana penunjang seperti buku atau sumber lain.

Saran yang dapat penulis berikan bagi guru dan calon guru, hendaknya lebih memperhatikan cara siswa menyelesaikan soal dan sarana prasana untuk menunjang proses pembelajaran. Untuk siswa hendaknya lebih sering mengerjakan latihan-latihan soal dan meningkatkan pemahaman dalam menyelesaikan soal-soal matematika.

\section{DAFTAR PUSTAKA}

Andriani, L. (2019). Analisis Kesalahan Mahasiswa Dalam Menyelesaikan Soal Himpunan di Program Studi Pendidikan Matematika UIN Suska Riau. Journal Cendekia: Jurnal Pendidikan Matematika, 03(02), 550-562.

Budiyono. (2008). Kesalahan Mengerjakan Soal Cerita dalam Pembelajaran Matematika. Jurnal Pedagogia, 11(1), 1-8.

Dym, C. L., \& Ivey, E. S. (2004). Principles of Mathematical Modeling. Amsterdam: Elsevier.

Gunawan, A. (2016). ANALISIS KESALAHAN DALAM MENYELESAIKAN SOAL CERITA PADA MATA PELAJARAN MATEMATIKA SISWA KELAS V SDN 59 KOTA BENGKULU. Jurnal PGSD: Jurnal Ilmiah Pendidikan Guru Sekolah Dasar, 9(2), 216-255.

Moleong, L. (2017). Metodologi Penelitian Kualitatif. Bandung: PT Remaja Rosdakarya.

Ndii, M. Z. (2018). Pemodelan Matematika. Yogyakarta: PENERBIT DEPUBLISH.

Nugroho, F. A. (2017). Kemampuan Siswa Menyelesaikan Soal Cerita SPLDV Ditinjau dari Taksonomi Solo Kelas X. Universitas Muhammadiyah Surakarta.

Rahmania, L., \& Rahmawati, A. (2013). Analisis Kesalahan Siswa Dalam ( Analysis of Student' S Errors in Solving Word Problems. Darul Ulum, 1(2), 165-174.

Rindyana, B. S. B., \& Chandra, T. D. (2013). Analisis Kesalahan Siswa dalam Menyelesaikan Soal Cerita Matematika Materi Sistem Persamaan Linear Dua Variabel Berdasarkan Analisis Newman.

Sari, P. R. (2018). Analisis Kesalahan Siswa SMP dalam Menyelesaikan Soal SPLDV. Prosiding Seminar Nasional Etnomatnesia.

Sugiyono. (2014). Metode Penelitian Pendidikan Pendekatan Kuantitatif, Kualitatif, dan R\&D. 
Identifikasi Kesalahan Siswa SMA dalam Membuat Pemodelan Matematika dan Penyebabnya, Rosdati Amira Bahir,

Bandung: Alfabeta.

Widowati, \& Sutimin. (2007). Buku Ajar Pemodelan Matematika. Semarang: FMIPA Universitas Diponegoro.

Zulfah. (2017). Analisis Kesalahan Peserta Didik pada Materi Persamaan Linear Dua Variabel di Kelas VIII MTS Negeri Sungai Tonang. Journal Cendekia: Jurnal Pendidikan Matematika, 01(01), 12-16.

Zulfah, Astuti, Insani, S. U., Zulhendri, \& Akbar, P. (2019). Development of Open-Ended Based Mathematics Problem to Measure High-Level Thinking Ability Development of Open-Ended Based Mathematics Problem to Measure High-Level Thinking Ability. Journal of Physics: Conference Series, 0-8. https://doi.org/10.1088/1742-6596/1315/1/012047

Zulyanty, M. (2019). NEWMAN ERROR ANALYSIS SISWA MADRASAH DALAM. Jurnal Cendekia: Jurnal Pendidikan Matematika, 03(02), 379-388. 